\title{
EUROPEANIZATION: A CRITICAL REALIST, DISCURSIVE INSTITUTIONALIST APPROACH
}

\section{Zoltan GRUNHUT, PhD}

Research Fellow, Hungarian Academy of Science, Centre for Economics and Regional Studies

grunhut@rkk.hu

\begin{abstract}
In the field of European Studies once so popular new institutionalist approaches are struggling to compete with the theoretical innovations proposed by post-structuralist scholarships. These latter interpretations debate that 'grand narratives' are proper explanatory frameworks to understand different political, economic and social processes merged under the umbrella-notion of Europeanization, so they favor more agent-based conceptualizations. While New Institutionalism aims to reflect on this challenge through epistemological and methodological attempts, mostly by discursive manners, yet this paper - with respect to the achievements of new empirical set-ups and designs argues that the ontological background should be addressed instead. For this goal the perspective of Critical Realism is crucial to note, and its suggestions about 1) multi-layered social reality, 2) metatheory, and 3) interconnectedness of subjects and objects in social science are pillars to be considered. All of these potential contributions highlight that scholars need to be reflexive as they are existentially embedded into the deep structures and linkages of generative mechanisms that they are theorizing. The more stable the belief that certain ontological conceptualizations are grasping the observable facts and events in a reflective way, the less reflexive the given thinker to realize the need for out-of-the-box ideas and hypotheses.
\end{abstract}

Keywords: Europeanization, Institutionalism, Structuralism, Critical Realism, Agency, Discourses.

\section{Introduction}

New institutionalist approaches, both in a theoretical and empirical sense, dominated studies on Europeanization during the early 2000s. At this time to conceptualize the interrelations between supranational and national level institutions and actors was appreciated by scholars with 
different backgrounds, just as to tackle empirically the same relationship. Beside the scientific importance, these studies, as policy researches, contributed to the assessment of multi-level governance practices and to the formulation of strategies and action plans too. Institutionalist, mostly comparative investigations on the progression (or stagnation) of Europeanization of different sectors and policy areas are still highly welcomed by decision-makers (take a look at the calls of EU's or national research funds), yet the innovation of original theoretical arguments has somehow slowed down. To be more precise, there is a shift to post-structuralist conceptualizations about Europeanization, and this is strongly challenging New Institutionalism, both its ontological aspects and its epistemological explanations (cf.: Neuman-Stanivukovic, 2014).

This paper aims to reflect on this trend - from a reframed but still institutionalist perspective. At first, it invokes Critical Realism as a conceptual source to shed light on how the structuralist rigidity of institutionalist approaches on Europeanization could be enriched through reflexivity; and secondly, it offers Discursive Institutionalism as a possibly adequate contribution to this goal. The main argument of the paper is divided into four chapters. The first gives an overview on the roots of New Institutionalism in European Studies, on how the concept was emerging in early European integration theories and then how it influenced studies on Europeanization particularly. The second chapter continues on this path, insofar as it presents some main institutionalist conceptualizations on Europeanization by shortly describing frameworks from Tanja Börzel, Claudio M. Radaelli and Thomas Risse. The third chapter then gives a short introduction to Critical Realism by highlighting its main aspects with particular focus on multilayered reality, meta-theory and interdependency between subjects and objects of social science. Finally, the fourth chapter suggests that Discursive Institutionalism could be a contribution that, by reflecting on the critical realist perspective, may enrich institutionalist studies on Europeanization through a reflexive stance.

\section{The roots of institutionalist approaches on Europeanization}

Early studies on European integration generally concern three main theoretical approaches: Federalism-confederalism, Neo-functionalism and Inter-governmentalism (Cini, 2007a). There is a trend among these conceptualizations, namely a continuous shift from supranational level processes to national level impacts on formulation of integration policies (Grunhut, 2017). Federalism-confederalism is based on normative constructivist arguments which highlight the 
importance of establishing organizations, adopting regulations, elaborating strategies, frameworks and actions plans, and introducing standardized procedures at the supranational level, while supporting a multi-cultural and multi-linguistic 'European togetherness' as a shared identity (Burgess, 2007). Although both within the federalist and the confederalist argumentations it is possible to differentiate rather centralist interpretations which are tempted to prioritize the supranational level and more decentralist tendencies that highlight the governmental functions of nation-states, yet these theories generally accept that the integration is a beneficial progression, so to facilitate its prospective advantages is a common interest for all parties (Burgess, 2000).

Neo-functionalism roots back to the concept of Ernst B. Haas (1958, 1961). In brief, theories based on this background underline how different supranational level processes, even just through their practical progression, without specific shifts to intentionally deepening the integration, support the stabilization and expansion of supranational cooperation. For this approach 1) integration spillover-impacts, 2) socialization of the elites, and 3) the roles of NGOs and interest groups at the supranational level are particularly interesting processes (Stroby-Jensen, 2007). Spillover-impacts are interpreted as general aftermaths of once established and continuously repeated institutional practices which lead to influence other forms of cooperation as schemes. The essential of this self-initiated framework is the interdependency between institutions (and agents) at supranational level: as the institutional tasks, responsibilities and functions are closely relating to each other, so the different institutions (and agents) of the integration cannot define their own legitimacy without other entities' functionality. Consequently, the more complex the integration becomes, the more dependent are its institutions (and agents), and because of this, the more likely that the network of cooperation will sustain (Rosamond, 2005).

The aspect of (re-)socialization of elites (or actors at the supranational level) is something closely related to the previous argument: as these actors are taking part in supranational processes, it is more probable that they are developing a kind of loyalty to the integration, rather through rational interests than deep emotional identification. Members of these elites are tasked to represent certain issues and perspectives, to build up networks, to formulate supranational level policy targets and action plans, and to implement these strategies. They are intensively involved into the work of supranational agencies which positions and roles make them being interested in sustaining these institutional frameworks and preserving their competencies as functionaries. This interdependency between the elites and the entities that provide them roles and tasks contributes 
to the evolution of supranational technocracy, undermining the rigid national interestrepresentation (Stroby-Jensen, 2007). Accordingly, both spillover-impacts and socialization of the elites explain the same phenomenon: the previous more from an institutional perspective, while the latter rather from the point of view of actors (Grunhut, 2017).

Finally, the third dimension, the roles of NGOs and interest groups at the supranational level should be understood as a legitimizing source for integration. As supranational cooperation progress, as the agencies develop a more comprehensive and more stable institutional framework by expanding their functions (spillover-impacts); and as the elites become more involved and more embedded into this structure, strengthening thereby their own roles and contributing to the competency- and capacity-building of agencies (socialization of the elites); so the importance of supranational level processes and representations are more appreciated for NGOs and interest groups too (Stroby-Jensen, 2007). The realization of these possibilities triggers these lobby entities to create supranational level branches, expand their networks, and to develop and communicate goals, policies and strategies for this level. All together, these efforts and actions effectively assist to the stabilization of supranational institutions.

While Federalism-confederalism is more an idealist interpretation of integration theory, Neo-functionalism is rather tempting to take into consideration realist perspectives. Intergovernmentalism is a step forward on this realist/neo-realist path by a clear message of emphasizing the importance of nation-states and national level processes (Cini, 2007b). Realist and neo-realist concepts of International Relations theory highlight that nation-states are motivated to act according to their rational interests in the global processes. Therefore, political, economic and social-cultural bi- and multilateral relations are shaped from the national perspectives of maximizing profits and minimizing losses. This logic makes the international space conflict-laden, heavily competitive and overly uncertain (Nugent, 1999). Based on this understanding, realist interpretation sees supranational integrations as temporary cooperation, which serve conflicting and power-dominated national interests, and due to this, the balance is not sustainable in an openend sense. Compare to this argument, Neo-realism admits that integrations could be long-term alliances, however the significant mechanisms, for this perspective too, are always occurring in the national contexts (Rosamond, 2000). Accordingly, Inter-governmentalism is focusing on multi-level political and economic governance, on representation of national interests in framing of supranational policies, and on the processes how national socio-political strategies embedded 
into the national socio-cultural features are formulated and channelized into supranational decision-makings (Moravcsik, 1998).

Inter-governmentalism by this realist/neo-realist and structuralist approach has opened the gate for New Institutionalism to conceptualize European Integration theory. After scholars turned their attention to national level social-political processes and to national socio-cultural specificities as constraints that shape supranational policies and strategies, a shift has unfolded with the aim to understand and explain the deepening (or the stagnation) of integration not through supranational developments (or regressions) but through linkages and adaptation mechanisms between supranational and national level institutions and agents (Grunhut, 2017). Beside the new scholarly interest, a new notion also became popular: after the focus moved from integration at the supranational level to multi-level institutional harmonization and convergence, 'Europeanization' emerged as a concept referring to these balancing mechanisms between top-down (from supranational to national; i.e. downloading) and bottom-up (from national to supranational; i.e. uploading), or in a more comprehensive sense ever fluctuating (cross-loading) causes and effects in the institutional framework (Grunhut and Bodor, 2016). Although studies, especially poststructuralist approaches on Europeanization, particularly from the fields of Sociology, Philosophy, Political Science, Anthropology and the so-called 'Studies' (such as Cultural Studies, Gender Studies, Queer Studies, Subaltern Studies, Decolonization Studies, etc.), have reinterpreted the concept later, yet the institutional argument emerged during the early 2000s remained an important understanding on Europeanization.

All three approaches of New Institutionalism are represented in European Studies. Historical Institutionalism (HI) considers the different regulations, organizations, policies, procedures, interventions, action plans and strategies as the basic units of researches, and it is interested in how the supranational and the national level are influencing each other through these mechanisms and tools; which level is rather the triggering one and which is the affected; what does the required reform imply in the addressed institutional contexts; how do these structural alterations and changes proceed; is there a process of harmonization or rather divergence (Rosamond, 2007). Accordingly, HI favors the comparison of existing, tangible formal structures and pays moderate attention to the agents' activities. It sees the institutional frameworks as closed contextual set-ups for political, economic and social-cultural processes, and it accepts that these structures are constantly affected by external impacts inducing different kinds of changes. The 
core problem to be investigated for this approach is the long term institutional (re-)framings through these competitive and frequently conflict-laden interactions between the supranational and the national level agencies. Therefore, HI understands Europeanization as an interventional effect that aims for national institutional reforms (Schimmelfennig and Sedelmeier, 2004, 2005).

Compare to HI, Rational Choice Institutionalism (RCI) places more intensive focus on the actors who are actively related to their formal structures. This approach considers actors as individuals motivated by rational interests to maximize their profits and minimize their losses during their interactions. It highlights that the institutional framework itself continuously creates situations that urge the participating actors to make decisions and take actions. Accordingly, RCI also concentrates on formal structures (such as policies, procedures, regulations, interventions, etc.), yet it assumes that actors, motivated by their rational interests, apply and alter institutions in a purposeful way. Therefore, $\mathrm{RCI}$ - compare to $\mathrm{HI}$ - proposes an active agent perception; although institutions provide frames for interactions, yet the actors are shaping and reshaping these set-ups by their rational choices and actions, i.e. not the structures as entities but rather rationality as an idea dominates the ongoing political, economic and social-cultural processes (March and Olsen, 1989, DiMaggio and Powell, 1991). For RCI Europeanization is a dynamic interrelationship between supranational and national level agencies and institutions; and the involved actors, by pursuing their rational interests, support these reforms as through a harmonized multi-level framework they can represent and realize their objectives in a more effective way (Börzel and Risse, 2003, Radaelli, 2003, Sittermann, 2008).

While RCI interprets individuals as rationally thinking actors, Sociological Institutionalism (SI) argues that agents' decisions are influenced not (only) by rationality but (also) by collectively accepted social values, norms, beliefs, codes, customs, rules, routines, perceptions, interpretations, understandings and taboos that are transmitted from generation to generation, with some alternations, of course, but showing stability on the whole (Grunhut, 2017). Individuals, while interacting with others (irrespective of this other is an exact person or a more abstract entity), are considering these social and cultural patterns as constraints that frame their ideas and actions. Of course, within a given society these patterns may differ very much by diverse social groups. It is also crucial to understand these patterns as influencing but not determining constraints. Notwithstanding, SI highlights that social and cultural patterns matter, so the functioning of institutions, the process of institutional changes, generally the institutional context itself is not 
independent from the existing socio-cultural context (North, 1990, 1991). Accordingly, SI is interested in how the formal structures are influenced by the cultural features of actors dealing with them (Fiori, 2002). For this approach, Europeanization is - just as for RCI - a process where national institutional changes are triggered by supranational expectations and guidelines, yet the outcomes of these reforms are depending primarily not on actors rationality, but on their cultural features, on their perceptions and interpretations, and how the expected institutional reconfigurations are adaptable to these existing social patterns (Börzel and Risse, 2003, Sittermann, 2008).

\section{Concepts of RCI and SI on Europeanization}

From the new institutionalist conceptualizations of Europeanization this paper is particularly focusing on Tanja Börzel's, Claudio M. Radaelli's and Thomas Risse's works. Before getting to the details, it is crucial to note that these concepts are seemingly outdated - most of the significant theoretical writings were published during the first half of the 2000s. A reason for this could be that nowadays New Institutionalism is far away to be the mainstream theoretical realm in the field of European Studies. Although there are some new trends, yet generally Institutionalism still misses to reflect on the post-structuralist turn that shifted the focus to auto-poietic identityand self-(re)construction, to language-based, discursively emerging identifications and perceptions, and to 'post-grand narrative' and 'post-grand theory' interpretations. Another reason could be behind the theoretical 'oldness' of applied institutionalist concepts on Europeanization is that they offer a quite straight framework and a pool of literatures for comparative empirical investigations.

Risse et al. (2001) sees Europeanization as an adaptation need (a 'misfit') in their model which induces national level institutional changes. Intermediary variables are the formal structures themselves and the agents' actions which together influence the institutional reform at national level (Grunhut, 2017). This latter factor is the variable that needs to be explained. However, the causal linkage among the variables is rather circular than linear one, insofar as the reform - the dependent factor -, i.e. the alteration of national institutions has impacts on the formal structures (if not, then the reform must be a total failure) and on the actors' perceptions and interpretations, on their agency as well. This should be seen, accordingly, as a dynamic interplay. But is it possible that the national reform also influences the adaptation pressure? Probably yes, thus this option 
means that Europeanization itself is up to modifications facilitated by national level institutional changes. Consequently, the model is using a circular cause and effect relationship (Grunhut, 2017).

Börzel and Risse (2003) in their framework, on the one hand, are building on the previous model, while at the same time they are enriching it with new factors. The same supranational adaptation pressure (misfit) identified by Risse et al. (2001) is the generative cause. Yet, Börzel and Risse are differentiating two pools of intermediary variables: the first dimension embraces the formal structures of the institutional context and the agents' actions related to this framework; while the other comprises different social patterns. The model, thus, aims to give a holistic interpretation in a sense of synthesizing interpretations of rationality and cultural constraints. The dependent variable, just as in the previous model, is the institutional reform at national level. However, Börzel and Risse give a more comprehensive understanding to the reform by distinguishing three aspects of it: 1) political activities (politics); public policies (policy); and political institutional system (polity) (Grunhut, 2017). Based on this extended meaning, the model aims to identify the implications of the reform in a more in-depth way that could contribute to the better understanding of the complexity of processes rather than considering them as mere tangible institutional changes. To put it in another way, Börzel and Risse emphasize that events and actions occur in the spectrum of politics and policies related to the reform are already facilitated by the adaptation pressure, therefore to focus just on the changes in the dimension of polity could be misleading. In line with this, the authors highlight that the national level institutional reform should be understood as a process affecting the formal structures and the more informal value- and normrelated social patterns of politics, policies and polities as well. And this comprehensive and interlinked progression is Europeanization itself.

While the previous model keeps the adaptation need as a generative mechanism and provides a complex explanatory framework to identify its impacts in all political institutional spectrums, Radaelli (2003) suggests an even more elaborated chain of linkages to unfold Europeanization as a process. For him the pressure, that facilitates national reforms, is not necessarily a direct intervention from the supranational level; it can also be an indirect impact in a sense of contextual change that make the national institutions, agencies and actors reflective in a self-initiative way. Radaelli in his model distinguishes two crucial dimensions. The so-called domains are the features influenced by the reform. These are the factors which appear in the framework of Börzel and Risse as politics, policy and polity. While that model is using a more 
general but quite clear description to group the institutional impacts, Radaelli aims to further unfold these - possibly affected - domains. He differentiates three categories: political structures; structure of representation and cleavages; and cognitive and normative structures. The first embraces elements mostly from the polity spectrum like structure of formal political institutions, public administration and legal system, as well as governance procedures, while this category also involves political parties, interest groups and NGOs as organizational actors. Radaelli claims that these are the domains of 'high politics'. Compare to these aspects, the structure of representation and cleavages as a category should be understood as a pool that embraces domains of 'grassroots politics' and features which influence the formulation of (top-down and bottom-up) policies. In light with this, Radaelli groups different business and civil agents, policy problems, policy principles and styles, as well as public policy resources and tools together in this category. Therefore, while the first dimension combines polity and politics, this second one rather encompasses features of politics and policy. Finally, among the cognitive and normative institutions the design lists values and norms, discourses, identities, legitimacy, as well as narratives, perceptions and understandings on governance.

So, these are the domains of the national level institutional framework that could be affected through reforms. Notwithstanding, Radaelli proposes crucial added values to the explanation of Europeanization as a process not by the affected domains but by distinguishing different generative mechanisms. He sees two main progressions: the vertical impact is basically the adaptation pressure (misfit) identified by both Risse et al. (2001), and Börzel and Risse (2003). The horizontal one is different, though, inasmuch these reforms are not triggered by the supranational level; these institutional changes are rather occurring in a self-initiative sense. There are two different vertical impact mechanisms in Radaelli's design: the 'classical' adaptation need requires institutional changes in a way of introducing new structural solutions, while the "negative integration' expects, instead, reforms through breaking down existing ones without applying any kinds of new frames. Nonetheless, the more interesting in the model is the horizontal adaptation mechanism which refers to the case when there is no direct pressure from the supranational level, yet the national institutional context still changes on its own initiative. Three cases of this are possible according to Radaelli: (1) when the supranational integration serves as an external legitimacy for the national reform; (2) when simply the practice of planning, strategy- and policymaking, and the 'idea' or 'culture' of cooperation (among different levels and agents) launches 
institutional changes; and (3) when it becomes recognized that governance is not a power-struggle for domination, but a problem-, goal-, task- and solution-oriented partnership among different actors (Grunhut, 2017). As it seems, the three cases refer to three types of actors and three different situations: the first is a self-initiated reform by the state (usually by the national government); the second is more an outcome of a multi-level and multi-actor macro cooperation, and in this case the initiative is a joint effort based on mutual interests; while the third case is a situation where national actors manage to develop a balanced micro (or meso) level institutionalized cooperation for different kinds of policies.

\section{A critical realist perspective}

In light of the review of new institutionalist perspectives on Europeanization and the more in-depth introduction to some main concepts, it is crucial to recognize that these interpretations consider institutional reforms as structural changes facilitated by interventions through the filters of certain external patterns like rationality or social and cultural constraints. These latter informal patterns that affect actors' ideas, decisions and attitudes should be seen as structures too. Accordingly, compare to HI, both RCI and SI by definition consider actors as active agents, yet these approaches also see subjects as pattern-followers who are adjusting their actorness to something the external representations, such as the idea of rationality and/or constraints of socialcultural values, norms, customs, conventions, rules, etc. Therefore, while there is an explicit agentbased perspective in these latter approaches, however it remains unfulfilled as to examine the different structures, among them informal but institutionalized patterns, is more important than to assume spontaneity, i.e. reflexive and critical agency from the actors. Due to this, both RCI and SI, and also their holistic synthesizations are rather approaches of rigid Structuralism than agentbased concepts. Consequently, all interpretations of New Institutionalism are closing themselves into theory-laden assumptions, which could mislead scholars in the task of understanding, observing and describing reality, both conceptually and empirically. So, on the one hand, this is a challenge to reflectivity, yet on the other, it is crucial to see that this scholarly perspective is not reflexive enough. And this is the point where Critical Realism offers innovations to new institutionalist - HI, RCI and SI - concepts on Europeanization.

This paper does not aim to give a broad (or even a brief) review on Critical Realism, so it just sums up some basic features of it (for a detailed introduction see: Archer et al. 1998, 
Danermark et al. 2002). First of all, Critical Realism tries to drive attention to causal mechanisms. It rejects empiricism in a sense of narrowing down reality to empirically observable phenomena. It favors 'critical methodological pluralism' which refers to an open-mindedness regarding to the selection among methodological opportunities. Critical Realism suggest to apply holistic methods in research designs in order to tackle the perceived problem from different angles and by various manners. It puts the most significant emphasis on ontological (i.e. conceptual and theoretical presumptions), and leaves the epistemological and methodological issues as something important, yet dependent tasks.

Probably, the main feature of Critical Realism is its meta-theory. It claims that reality is multi-layered or arranged in levels (consequently it is not 'flat'), and every level contains qualitatively new and different specificities (Bunge, 1979). These layers are three separated but dynamically interrelated domains. First, there is the empirical domain of the observable phenomena of 'facts' and 'events'. This is the easiest to detect, both theoretically and empirically. Yet, it is just a part of reality. Moving to the second layer, it is the actual domain where things 'actually' happen irrespectively of we could observe them or not. Therefore, the inner-mechanisms of the actual domain are causes to the observable factors of the empirical domain, which are effects in this relationship. However, as Critical Realism argues, the mechanisms of the actual domain are just intermediary variables to an even deeper layer of reality - to the real. From this latter domain starts the whole generative process of causality, there are the 'ultimate causes' - as Critical Realism interprets the last realm of its framework (Bhaskar, 1978, 1986, 1989).

Why is that? Because what we observe in the empirical domain (as facts or events) is not necessarily the same thing what really happens in the actual domain. Thus, there is a difference between how we describe reality and actually what it is, i.e. between our conceptualizations on reality and the real world out there. If we saw the reality by first impressions in an adequate way, then science would not be anything else than mere data collection and data interpretation. Therefore, to understand, to perceive the mechanisms of the actual domain is a crucial task to do. Yet, if these mechanisms of the actual domain really happen or not, this is what depends on the facilitating causes of the real domain.

Some could ask: why three layers of reality and not four, or rather five? Why do not we perceive in advance that the real domain also contains a deeper layer of reality with more original causes in the link of causality? The answer to this is pretty simple: Critical Realism distinguishes 
three layers not due to the causal chain of links, but based on first-handed observability of reality. There could be dozens of intermediary variables between the original cause and the final effect. However, observability of reality cannot be more complex than three layers: the empirical domain is always observable; the actual domain is partly observable and partly not; while the real domain is always non-observable by first impression. This is the responsibility of science: to go along this path to the real (Archer 1995). A question remains, though. How can a scholar be sure that by revealing more and more causes, the last one in the link of relationship is really the triggering factor from the real domain and not another intermediary cause still from the actual domain? Fortunately or unfortunately, (s)he cannot be sure, ever.

At here, this paper should switch from Critical Realism to science philosophy to cite the theories of Popper about falsification, Kuhn about paradigm shift, Feyerabend about methodological anarchism, and Rorty about inter-vocabularism and contingencies. However, the scope and the limits of this argument do not allow us to continue on this way (see: Vandenberghe, 2014). What is crucial to note that knowledge on reality is always just a snapshot; knowledge is building on previous knowledge. And beside this temporariness, another essential aspect is that knowledge is never independent from the 'knower', from the subject who gain and grasp it (the 'truth' is a 'truth' just for 'me' and never for 'you') (Collier, 1994). Based on this interpretation, Cognitive Relativism even doubts the existence of reality itself, and claims that it is a hermeneutically, in an auto-poietic way (narratively and performatively) self-constructed delusion, influenced by historical, cultural and social impacts and individual features. Critical Realism aims to take the middle way in this debate between foundationalist and anti-foundationalist philosophy, inasmuch it stresses that reality exists independently from our knowledge on it, yet our knowledge on reality is always theory-dependent, however it should not be rigidly theory-determined! Consequently, yes, Critical Realism also admits that knowledge is socially (culturally) embedded (discussed, accepted, transmitted, falsified in a dynamic process), yet the aim to continuously develop it is triggered by external 'facts' and 'events', i.e. something must be 'out there' (Sayer, 1992). The obvious challenge is that without a 'knower' it is impossible to create knowledge; it is infeasible to compare our knowledge on reality to the 'real' reality 'out there'. This is why Critical Realism is pushing for meta-theoretical thinking, as our knowledge on reality will always remain theory-laden, yet by discussing new conceptualizations, it is achievable to enrich our perspectives [although, according to Rorty (1989), this continuous theorization won't transport us closer to the 
'real' reality, thus for his pragmatic approach the practical usefulness and the broad acceptability of concepts - which two features should be interrelated - are more important than mere theoryelaborations] (Collier, 1994).

To turn back to the main argument of this chapter, if we take into consideration the multilayered character of reality stressed by Critical Realism, it drives our attention to an interesting aspect. The objects of natural sciences are naturally produced and socially defined, while the objects of social sciences are socially produced and socially defined. Furthermore, the objects of natural sciences are neutral, passive about the knowledge on them, and they remain unchanged irrespectively of how they are perceived and defined, while the objects of social sciences are - one way or another - including other people, they are interested in the knowledge about them, and they could react to how they are perceived and defined. Hence, while gaining knowledge in the case of natural sciences is hermeneutical, the same searching in social sciences is 'double-hermeneutical', inasmuch scholars of this field perceive and interpret, i.e. conceptualize others' ideas on reality. And while these two realms of concepts - the scientific and the lay or 'common sense' one - could interplay for the good of all parties participating in the search of reality, yet there is also a chance that the two are heavily contesting and struggling or wrongly collaborating with each other, and, instead of revealing, they are blurring reality in a pathological sense. Consequently, to get from the empirical domain to the actual one, and from there to the real domain in natural sciences solely depends on the subject, while the progression of the same efforts in social sciences is on the shoulders of both the subjects and the objects of searching reality (Sayer, 1992). This is why lay knowledge and lay concepts should never be closed out from social science's understandings on reality.

\section{Discursive Institutionalism}

The perspective of Critical Realism opens up the gate to add different comments and remarks to institutionalist approaches on Europeanization. What this paper highlights from the brief summary of the previous chapter is that 1) reality is multi-layered and the different levels are interrelating in a dynamically causal sense through generative mechanisms; 2) there is a need for meta-theoretical thinking to reveal these generative mechanisms; 3 ) the objects and the subjects of social sciences should not consider each other as separated agents in searching of reality. Based on the aforementioned three fundamental statements, this paper argues that it is worth to think 
about a reflexive reconceptualization of $\mathrm{HI}, \mathrm{RCI}$ and SI on Europeanization along the way to make these approaches 1) less bounded by obvious empirical observations; 2) more open to reflexive theoretical assumptions; and 3) more sensitive towards 'common sense' conceptual inputs. For this attempt, Discursive Institutionalism (DI) may offer an opportunity to evaluate.

DI is not a new concept, it is also applied in the field of European Studies for some times (Lynggaard, 2012). It argues that discourses are both 'institutions' and 'practices'. Respective to the latter sense, discourses are communicative interactions that produce and reproduce, or formulate and debate meanings, ideas, narratives, categorizations, perceptions and understandings about physical and social realities. Yet, discourses are also 'institutions' inasmuch the mainstream or hegemonic, on the one hand, and the 'sidelined/underdog' narratives, symbols, rhetorical statements, conceptual articulations and conversation styles, on the other, are both framing the cognitive schemes and the inter-subjective interactions (Kjær and Pedersen, 2001). Accordingly, knowledge and power are interlinked in a discursive way. In an ideal case, discourses serve as platforms for communicative interactions based on recognition (mutual acknowledgment), however it is more observable that discourses are laden with social conflicts, competitions, struggles and hierarchical relations. Reflecting on HI, RCI and SI, i.e. on the three original approaches of New Institutionalism, DI argues that the examination of discourses is a crucial added-value in the research of institutional changes as these reform processes are represented not just in various forms of performativity, but also in the relevant actors' narratively expressed perceptions, interpretations, conceptualizations, understandings, symbols and framings (Schmidt, 2008). Furthermore, DI could offer deeper insights about the aspect of actors' ideational substances respective to the cognitive logics/normative requirements of certain institutional reconfigurations that they are performatively pushing for (Schmidt, 2005). Therefore, if we accept that Europeanization is a process of adaptation between the supranational and the national level where the latter needs to be changed according to the technical/cognitive and/or appropriative/normative guidelines proposed by the former one, then DI offers an adequate approach which is focusing on how the relevant actors (e.g. decision-makers, stakeholders, experience-holders, beneficiaries, experts, members of advocacy groups and epistemic communities, different social groups, etc.) perceive this expected adaptation process (Schmidt, 2010). By this added input of discourses, institutionalist explanations on Europeanization could be enriched with crucial findings in order to examine structural harmonization/divergence in a more in-depth way. Inquiries on discourses 
may help to understand how different meanings, ideas, perceptions, interpretations and understandings, i.e. set of various preferences are combined (or heavily contested) to (de)produce an accepted (or strongly disputed) policy of institutional choice in the ever changing socio-political contexts (Schmidt, 2007).

The framework of DI generally applied in the field of European Studies is based on two analytical pillars: discursive constructs and discursive agency. The former one is interested in how the supranational expectations and guidelines about national level institutional reforms are 'translated' by different actors of the domestic arena; how they are interpreting and reinterpreting these aspects, how they are adding new perceptions and understandings to them, or how they are neglecting certain criteria (Lynggaard, 2007). This focus is analyzing how inputs from the supranational level and the national level are combined into a discourse of giving meanings to various phenomena of social reality, and how interpretations of these inputs from the different levels are harmonized or contested, completing and enriching or deforming and undermining each other. Compare to this, discursive agency is more concentrating on actors and on their specific arguments that motivate/inspire them to enter discourses (Lynggaard, 2012). Therefore, 'discursive actorness' and 'discursive entrepreneurship' is the core problem of this analytical approach, the relation between actors, roles, powers, conflicts, abilities and capabilities, and, of course, the impacts of all these factors on the formulation of discourses and narrative meanings, perceptions, symbols, understandings and styles.

Obviously, DI aims to reflect on HI, RCI and SI from an agent-based, micro-oriented and constructivist perspective when it argues the importance of discursive constructs and agency. Critiques debate that this shift has any ontological novelty compare to what New Institutionalism already theorized, while they admit that the intensive focus on discourses could be seen as an epistemological or rather more as a methodological development (cf. Bell 2011, 2012). So the question is justified: from a critical realist perspective, that highlights the outmost relevancy of continuous (re)conceptualizations, why DI is crucial to consider? To answer this it should be noted again that Critical Realism stresses 1) the multi-layered dimensionality of social reality; 2) the need for meta-theoretical thinking; and 3) the interconnectivity of subjects and objects in social sciences. These criteria all emphasize that producers of intellectual knowledge should go beyond reflectivity, i.e. on the scholarly task of describing the social facts, events and actions in the most proper way possible, and they rather need to strive for reflexivity. Or to put it differently, they 
need to realize their existential embeddedness into reality. To reach this perspective of reflexive scientization, intellectual knowledge/conceptualizations should consider lay ideas as ontological sources for meta-theoretical aspirations, insofar as the structures and generative mechanisms of the deep layers that shape and reshape human agency through formal and informal institutions, discourses, meanings, 'common sense' concepts, etc. could affect 'intelligentsia' too. This is why this paper finds DI as a potentially useful approach to enrich HI, RCI and SI theories on Europeanization; because it aims to map out lay people's way of thinking and way of doing things. To address changes (or stabilities) in the institutional context through a more adequate epistemological and methodological framework, it is a great achievement. But from a critical realist perspective this has secondary importance. The reflexivity of thinkers is much more relevant as that could help to develop new concepts and out-of-the-box hypotheses. Observing and analyzing how structures and causally linked mechanisms are influencing lay people's cognitive/normative understandings and praxes, and also their contextual frameworks from sociopolitical constellations, through formal and informal institutions, to discourses and so on - this is what Critical Realism suggests for reflexive ontological conceptualizations, and this is why DI could support New Institutionalism generally and institutionalist scholarships on Europeanization particularly.

\section{Conclusion}

New institutionalist approaches on Europeanization are in need of theoretical innovations, and it seems hardly enough to propose holistic conceptualizations of HI, RCI and SI - suggested by Juppile (2006) and Kauppi (2010). Although synthesized theoretical frameworks could build on various advantages of different approaches while they could manage more effectively the potential weaknesses, so these theories may be more reflective, yet without reflexivity, i.e. without considering that intellectual thinkers are also influenced by structures and mechanisms hidden in the deep layers of reality, the inherent structural rigidity of these conceptualizations remains. Critical Realism warns us that the observable facts and events are usually more complex than how we perceive and interpret them. Scientific attempts to understand the 'world-out-there' are always theory-laden individual understandings. The more scholars believe that their explanatory approaches are reflective, the less they are tempted to be open for self-reflexivity. While it seems to be a challenge that the objects of social sciences are interested in how they are defined and 
interpreted, so they can react to the subjects' theorizations on them, which is not the case in natural science, yet it is better to see this constellation of necessary inter-subjective linkage as something beneficial to intellectual knowledge producers; this inspiration is what could make them stay reflexive through interactions with lay people. This double hermeneutical process of understanding and describing social reality should motivate scholars to see themselves as agents existentially embedded into the socio-political, socio-cultural and socio-moral constellations that they are analyzing. This should not be underestimated!

The importance of DI could be seen as a methodological innovation about tackling and investigating institutional changes (stabilities) more dynamically through lay perceptions and interpretations. Notwithstanding, the present paper emphasizes the relevance of DI not about reflectivity, but from an ontological point of view if scholars are open for reflexive reconsiderations of their original concepts. To pay attention for agency is crucial if scholars aim to debate the determining/influencing roles of deep structures and mechanisms, and they question the scientific reliability of explanatory 'grand narratives' and 'grand theories'. This is what poststructuralism is pushing for in the field of European Studies and particularly in scholarships about Europeanization. However, to observe agency is relevant also for understanding the multi-layered character of social reality, how deep structures and mechanisms are working, and how these causes and effects are influencing scholars' perceptions and interpretations, i.e. their conceptualizations and praxes as well. Consequently, New Institutionalism in the field of European Studies could gain ontologically from DI if it is used for critical realist reflexive theorizations.

\section{Acknowledgement}

Project no. PD124706 ('The Normative Actorness of the European Union') has been implemented with the support provided from the National Research, Development and Innovation Fund of Hungary, financed under the PD17 funding scheme. The research was supported, on the other hand, by the Pallas Athéné Domus Animae (PADA) Foundation (Analytical Approach on Europeanization).

\section{References}

1. ARCHER, M. (1995) Realist Social Theory: The Morphogenetic Approach. Cambridge: Cambridge University Press. 
2. ARCHER, M., BHASKAR, R., COLLIER, A., LAWSON, T., and NORRIE, A. (eds.) (1998) Critical Realism: Essential Readings. London: Routledge.

3. BELL, S. (2011) Do We Really Need a New 'Constructivist Institutionalism' to Explain Institutional Change? British Journal of Political Science, 41 (4), pp. 883-906.

4. BELL, S. (2012) Where are the Institutions? The Limits of Vivien Schmidt's Constructivism. British Journal of Political Science, 42 (3), pp. 714-719.

5. BHASKAR, R. (1978) A Realist Theory of Science. Hassocks: Harvester Press.

6. BHASKAR, R. (1986) Scientific Realism and Human Emancipation. London: Verso.

7. BHASKAR, R. (1989) Reclaiming Reality: A Critical Introduction to Contemporary Philosophy. London: Verso.

8. BÖRZEL, T. A. and RISSE, T. (2003) Conceptualizing the Domestic Impact of Europe. In: FEATHERSTONE, K. and RADAELLI, C. M. (eds.) The Politics of Europeanization. Oxford: Oxford University Press. pp. 57-80.

9. BUNGE, M. (1979) Causality and Modern Science. New York: Dover.

10. BURGESS, M. (2000) Federalism and the European Union: Building of Europe 1950-2000. London: Routledge.

11. BURGESS, M. (2007) Federalism and Federation. In: CINI, M. (ed.) European Union Politics. Oxford: Oxford University Press. pp. 69-84.

12. CINI, M. (ed.) (2007a) European Union Politics. Oxford: Oxford University Press.

13. CINI, M. (2007b) Intergovernmentalism. In: CINI, M. (ed.) European Union Politics. Oxford: Oxford University Press. pp. 99-116.

14. COLLIER, A. (1994) Critical Realism: An Introduction to Roy Bhaskar's Philosophy. London: Verso.

15. DANERMARK, B., EKSTRÖM, M., JAKOBSEN, L. and KARLSSON, J. C. (2002) Explaining Society. Critical Realism in the Social Sciences. London: Routledge.

16. DIMAGGiO, P. J. and POWELL, W. W. (1991) Introduction. In: DIMAGGIO, P. J. and POWELL W. W. (eds.) The New Institutionalism in Organizational Analysis. Chicago: University of Chicago Press. pp. 1-27.

17. FIORI, S. (2002) Alternative Visions of Change in Douglass North's New Institutionalism. Journal of Economic Issues, 36 (4), pp. 1025-1043. 
18. GRUNHUT, Z. (2017) Concepts, Approaches and Methods on Europeanisation - A Metaanalysis. Eastern Journal of European Studies, 8 (1), pp. 157-176.

19. GRUNHUT, Z. and BODOR, A. (2016) A Synthesising Approach on Europeanisation. Europolis, 10 (1), pp. 31-50.

20. HAAS, E. B. (1958) The Uniting of Europe. Stanford: Stanford University Press.

21. HAAS, E. B. (1961) International Integration: The European and the Universal Process. International Organizations, 15 (3), pp. 66-92.

22. JUPILLE, J. (2006) Knowing Europe: Metatheory and Methodology in European Union Studies. In: CINI, M., and BOURNE, A. (eds.) Palgrave Advances in European Union Studies. Basingstoke: Palgrave. pp. 209-232.

23. KAUPPI, N. (2010) The Political Ontology of European Integration. Comparative European Politics, 8 (1), pp. 19-36.

24. KJAER, P. and PEDERSEN, O. (2001) Translating Liberalization: Neoliberalism in the Danish Negotiated Economy. In: CAMPBELL, J. and PEDERSEN, O. (eds.) The Rise of Neoliberalism and Institutional Analysis. Princeton: Princeton University Press. pp. 219-248

25. LYNGGAARD, K. (2007) The Institutional Construction of a Policy Field: A Discursive Institutional Perspective on Change within the Common Agricultural Policy. Journal of European Public Policy, 14 (2), pp. 295-314.

26. LYNGGAARD, K. (2012) Discursive Institutional Analytical Strategies. In: EXADAKTYLOS, T. and RADAELLI, C. (eds.) Research Design in European Studies. Establishing Causality in Europeanization. London: Palgrave. pp. 85-104.

27. MARCH, J. G. and OLSEN, J. P. (1989) Rediscovering Institutions. The Organizational Basis of Politics. New York: Free Press.

28. MORAVCSIK, A. (1998) The Choice of Europe: Social Purpose and State Power from Messina to Maastricht. London: UCL Press.

29. NEUMAN-STANIVUKOVIC, S. (2014) Europeanization: A Poststructuralist Approach. PhD thesis. Groningen: University of Groningen.

30. NORTH, D. C. (1990) Institutions, Institutional Change, and Economic Performance. Cambridge: Cambridge University Press.

31. NORTH, D. C. (1991) Institutions. Journal of Economic Perspectives, 5 (1), pp. 97-112. 
32. NUGENT, N. (1999) The Government and Politics of the European Union. Basingstoke: Palgrave.

33. RADAELLI, C. M. (2003) The Europeanization of Public Policy. In: FEATHERSTONE, K. and RADAELLI, C. M. (eds.) The Politics of Europeanization. Oxford: Oxford University Press. pp. 27-56.

34. RISSE, T., COWLES, M. G. and CAPORASO, J. (2001) Europeanization and Domestic Change: Introduction. In: COWLES, M. G., CAPORASO, J. and RISSE, T. (eds.) Transforming Europe. Europeanization and Domestic Change. Ithaka and London: Cornell University Press. pp. 1-20.

35. RORTY, R. (1989) Contingency, Irony and Solidarity. Cambridge: Cambridge University Press.

36. ROSAMOND, B. (2000) Theories of European Integration. Basingstoke: Palgrave.

37. ROSAMOND, B. (2005) The Uniting of Europe and the Foundations of EU Studies: Revisiting the Neo-functionalism of Ernst B. Haas. Journal of European Public Policy, 12 (2), pp. 237254.

38. ROSAMOND, B. (2007) New Theories of European Integration. In: Cini, M. ed. European Union Politics. Oxford: Oxford University Press. pp. 117-135.

39. SAYER, A. (1992) Method in Social Science: A Realist Approach. London: Routledge.

40. SCHIMMELFENNIG, F. and SEDELMEIER, U. (2004) Governance by Conditionality: Rule Transfer to the Candidate Countries of Central and Eastern Europe. Journal of European Public Policy, 11 (4), pp. 661-679.

41. SCHIMMELFENNIG, F. and SEDELMEIER, U. (eds.) (2005) The Europeanization of Central and Eastern Europe. Ithaca, NY: Cornell University Press.

42. SCHMIDT, V. A. (2005) The Role of Public Discourse in European Social Democratic Reform Projects. European Integration online Papers (EIoP), 9(8).

43. SCHMIDT, V. A. (2007) Trapped by Their Ideas: French Élites' Discourses of European Integration and Globalization. Journal of European Public Policy, 14 (7), pp. 992-1009.

44. SCHMIDT, V. A. (2008) Discursive Institutionalism: The Explanatory Power of Ideas and Discourse. Annual Review of Political Science, 11 (1), pp. 303-326. 
45. SCHMIDT, V. A. (2010) Taking Ideas and Discourse Seriously: Explaining Change through Discursive Institutionalism as the Fourth 'New Institutionalism'. European Political Science Review, 2 (1), pp. 1-25.

46. SITTERMANN, B. (2008) Europeanisation - A Step Forward in Understanding Europe? Working paper series, Westfälische Wilhelms-Universität Münster.

47. STROBY-JENSEN, C. (2007) Neo-functionalism. In: CINI, M. (ed.) European Union Politics. Oxford: Oxford University Press. pp. 85-98.

48. VANDENBERGHE, F. (2014) What's Critical about Critical Realism? London: Routledge. 